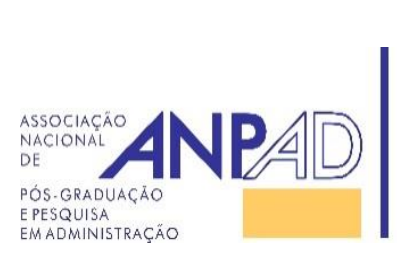

Available online at

http://www.anpad.org.br/bar

BAR, Rio de Janeiro, RJ, Brazil, v. 15, n. 4, art. 1, e170119, 2018

\title{
Measuring accrual-based IPSAS implementation and its relationship to central government fiscal transparency
}

\author{
Sigit Wahyu Kartiko ${ }^{1,2}$ \\ Hilda Rossieta ${ }^{1}$ \\ Dwi Martani ${ }^{1}$ \\ Trisacti Wahyuni ${ }^{1}$
}

University of Indonesia, Faculty of Economics and Business, Depok, Indonesia ${ }^{1}$ Ministry of Finance, Jakarta, Indonesia ${ }^{2}$

Received 12 October 2017. This paper has been with the authors for two revisions. Accepted 5 September 2018. First published online 21 November 2018. Fast-track article from the 6th International Accounting Conference held in Yogyakarta, Indonesia, August 27-29, 2017. Editor's note. Salomão Alencar de Farias served as Associate editor for this article. 


\begin{abstract}
This study aims to explore government accrual-based IPSAS implementation level measurements and to test the measures associated with central government fiscal transparency. Performing content analysis and Confirmatory Factor Analysis (CFA) on a sample covering 77 countries from 2008 to 2015, measurement indicates the relative importance and significance of financial performance statements and accrual accounting policies, such as nonexchanged and exchanged transactions as accrual level constructors. Conducting panel data regression, we find that accrual level scores meet the requirements of the external validity test, as indicated by their positive association with the International Budget Initiative's (IBP) fiscal transparency index. The evidence suggests that central governments should strategically implement accrual-based IPSAS. Accrual practices (implicitly or explicitly) based on IPSAS strengthen fiscal transparency when it prioritises developing accrual accounting policies substantially rather than accrual commitment and the completeness of reports.
\end{abstract}

Key words: accrual-based IPSAS; fiscal transparency; confirmatory factor analysis. 


\section{Introduction}

Good public governance principles have become a foundation used by several countries to reform their public administration. Enhancement of accountability, transparency, efficiency, effectiveness, responsiveness, and the rule of law are the key objectives for government to successfully deliver public desires (Organisation for Economic Co-operation and Development [OECD], 2011). One of the most interesting concerns is with taxpayers' and investors' accessibility demands towards the central government's public finance policy. Government responses have been to increase their public financial, or fiscal, transparency by reforming their Public Financial Management (PFM) practices (Martí \& Kasperskaya, 2015).

The positive trend towards fiscal transparency has pervasively spread across entire countries (Seifert, Carlitz, \& Mondo, 2013). Based on the guidelines for fiscal transparency provided by prominent international organizations - such as the International Monetary Fund (IMF), the Organization for Economic Co-operation and Development (OECD), the International Organization of Supreme Audit Institutions (INTOSAI), and the World Bank - the International Budget Partnership (IBP) documented that more than $22 \%$ of around 100 central governments surveyed had sufficient fiscal transparency (IBP, 2015). Since the recovery from the 2008 global financial crisis (Berger, 2012), this percentage has been growing steadily, simultaneously with PFM reforms. Using statistical reports as a fiscal transparency measurement, Wang, Irwin, and Murara (2015) also demonstrated a positive trend in the availability of Government Finance Statistics (GFS) in OECD countries.

Some argue that better fiscal transparency has a positive link with most countries' PFM reforms (De Renzio \& Masud, 2011; Martí \& Kasperskaya, 2015). Public sector accrual accounting practices as PFM best practices - assist in the provision of richer information with a single set of accounting procedures for the decision-making process (see Alt, Lassen, \& Skilling, 2002; Chan \& Zhang, 2013; Diamond, 2002; Guthrie, 1998). Therefore, most central governments have made extra efforts to improve recording and to present their advanced financial transactions by upgrading their book-keeping systems. PricewaterhouseCoopers $(\mathrm{PwC}, 2013)$ demonstrated the increasing trend toward accrual accounting in central governments around the world. It was predicted that more than $63 \%$ of countries would convert their traditional cash basis to accrual accounting by 2018 .

However, accrual practices have been quite varied across central governments. State-of-the-art central government accrual accounting implementation reflects the resultant factor of such political compromises, cultural backgrounds (Hyndman \& Connolly, 2011; Lapsley, Mussari, \& Paulsson, 2009), economic structures, and characteristics of business infrastructure (Pina \& Torres, 2003). The factors underlying the recognition, measurement, and presentation (RMP) of accrual policies were mainly categorized as (a) GAAP businesslike, (b) statistical-based, and (c) accrual-based IPSAS (Christiaens, Vanhee, Manes-Rossi, Aversano, \& Cauwenberge, 2014; PwC, 2014). The variation in their adoption leads to incomparability and inconsistency in publicly provided government financial indicators. Even when a government financial performance outlook was provided by international financial institutions (i.e., the IMF or the World Bank), the financial adjustment inside its metadata - reflecting methodological soundness - potentially reduced its fiscal information quality (Giosi, Brunelli, \& Caiffa, 2015).

Accrual-based IPSAS as a de-facto international public sector accounting standard has been gradually, partially, or fully - referred by several country standard-setters to overcome such information quality problems. The rationale behind IPSAS adoption is that its comparability and consistency for governmental reporting systems cover systematic public fund RMP rules (International Federation of Accountants [IFAC], 2014). Based on International Financial Report Standards (IFRS), IPSAS is compatible with the recent fair value model of the financial instrument that attracted government entities to improve their public asset and liability valuations (Bolívar \& Galera, 2012). IPSAS provides not only a full set standard of procedures for advanced credit-economy transactions (Chan \& Xu, 2012) but also 
consensus on the treatment of special government entity transactions and presentations (i.e., nonexchanged revenue transactions and budgetary reports) (Diamond, 2002).

Previous studies have been attempted by considering accrual-based IPSAS implementation levels, with some limitations. For example, they attempted to simplify conformity of accrual-based IPSAS relying on main presentations (Pina \& Torres, 2003), identify accrual-based IPSAS regardless of RMP procedures (Christiaens et al., 2014), build a conformity index without non-exchanged transactions policies and employee benefits (Benito, Brusca, \& Montesinos, 2007), and produce a highly detailed disclosure checklist based on IPSAS paragraphs (Ernst and Young [EY], 2012). The accounting maturity level was developed for nine (9) European countries. However, the maturity of each of the accounting policies with accrual-based IPSAS was constructed based on the European Public Sector Accounting Standards (EPSAS) context (PwC, 2014).

This study aims to explore accrual-based IPSAS implementation level measurement and test the measures associated with central government fiscal transparency by extending or contributing previous studies in three aspects. Firstly, we measure the accrual-based IPSAS level index in an intuitive manner based on hierarchical accrual adoption information from simple to complex identification statements. It builds upon the following information: (a) whether accrual adoption has declared - implicitly or explicitly - accrual-based IPSAS (accrual commitment), (b) whether elements of financial statements financial position, financial performance, cash flow, changes in equity, and notes of financial statements - have been formally publicly provided (accrual report), and (c) how the specific accounting transaction policies of accrual characteristics substantially conform with IPSAS policies (accrual policy). Secondly, it completes the methodological aspect of index construction. Content analysis scored the highlighted criteria, relying on published central government financial statements and accounting policies. Further, confirmatory factor analysis was obtained for the internal validity of each accrual dimension relationship and loading factors that construct accrual level as the latent variables. Thirdly, this article demonstrates an empirical test involving 77 central governments (OECD, non-OECD, BRICS) from 2008 to 2015 for panel data - instead of cross-sectional - accrual accounting development and extends Bolívar and Galera's (2012) and Galera and Bolívar's $(2007,2010,2011)$ studies of the impact of accrual-based IPSAS on government financial or fiscal transparency.

This article is organized as follows: first, it presents the theoretical framework of accrual accounting adoption and hypothesis development regarding its association with fiscal transparency. The second section outlines the research method for building the accrual level index and the regression model. The third part discusses the results and provides concluding remarks on this study.

\section{Literature Review and Hypothesis Development}

\section{Government accounting and fiscal transparency}

Improving transparency by modernizing government accounting practices is supported by agency theory. It has been assumed that bureaucratic policymakers engage in opportunistic behavior to obscure financial information from mandate givers, such as parliament, legislation, voters, or authorities (see Alt et al., 2002; Debrun \& Kumar, 2007; Irwin, 2012). Better quality fiscal information assists policymakers conduct their fiscal actions transparently to demonstrate public governance practices, reduce abuse of power, and safeguard government assets (see Cicatiello, De Simone, \& Gaeta, 2017; De Renzio \& Masud, 2011; Hameed, 2005; Wehner \& Renzio, 2013).

The terms accounting stratagems (Irwin, 2012; Weber, 2012), creative accounting (Luder, 2000; Reischmann, 2016), and fiscal illusions (Guillamón, Bastida, \& Benito, 2011) have been highlighted to express the problematic accounting choices of agents or policymakers. Policymakers will choose a reporting method to articulate public fund usage that reflects their best performance in the presence of voters (see Copley, 1991; Zimmerman, 1977). Together with democratization, political competition, and 
high tax rates, the policymakers or elected politicians need to satisfy voters by using public resources in a transparent way (Arapis \& Reitano, 2017; Zimmerman, 1977). Thus, the competitive situation between politicians and voters will result in the demand for better procedures, standards, or regulation of choices for financial transparency reports (Baber \& Sen, 1984).

Within the concept of public financial management, financial or fiscal transparency, according to Heald (2012), is defined as the systematic disclosure of government actions that have consequences for government accounts: revenues, expenditures, finance, liabilities, assets, and ownership changes. It stresses the openness of government policy actions that should be coherently disclosed in every PFM cycle: budget formulation, execution, and year-end report processes. In addition, the IMF $(2012$, p. 4) highlights fiscal transparency as "[t]he clarity, reliability, frequency, timeliness, and relevance of public fiscal reporting and the openness to the public of government's fiscal policy-making process...". It emphasizes the principles of fiscal transparency, such as (a) the comprehensiveness, relevance, timeliness, and reliability of a government's financial position and performance reports; (b) clear fiscal and budget objectives and targets; and (c) adequate fiscal management and coordination for the decisionmaking process.

Furthermore, fiscal transparency quality can be identified from the credibility of fiscal policy indicators that are internationally published as fiscal outlook or finance statistics (Cicatiello et al., 2017; Wang, Irwin, \& Murara, 2015). In macroeconomics theory, fiscal policy itself involves government actions to adjust government expenditure levels $(\mathrm{G})$, tax rates $(\mathrm{T})$, and sovereign debt (D) to intervene in the national economy (GDP) (Greenwood, 2018), thus generating fiscal sustainability indicators such as total gross debt, net worth, net financial worth, fiscal gap, net debt/total revenues, and fiscal dependency (International Public Sector Accounting Standards Board [IPSASB], 2013).

The role of the accounting system contributes to fiscal report quality. The credibility of microaccounting transactions at the entities' level contributes to the quality of government financial information (Luder, 2000; Mellor, 1996). Government accounting procedures - notably accrual-based accounting - compile budgetary accounts to encourage openness of off-budget, extra-budget, offbalance sheet, long-term financial rights, obligations, and future cash flows, which should be coherently accounted in PFM cycles, thus enhancing the integrity and reliability of the fiscal condition (Chan \& Zhang, 2013; Mellor, 1996). For international comparability and transparency, accounting information needs an adjustment of metadata to publish fiscal accounts based on the macroeconomic perspective as financial statistics reports (Giosi et al., 2015; Luder, 2000). Therefore, the procedural choices of accounting systems determine the quality of both fiscal management and fiscal outlook.

\section{Strengthening fiscal transparency: what does IPSAS already offer?}

Currently, the growing demands for government financial transparency have affirmed IPSAS as a global standard. Advocating IPSAS adoption to "strengthen public finance management ..., thereby increasing transparency and accountability" (IPSASB, 2016, p. 16) is often justified as "international best practices" (Heald, 2012, p. 46). Sellami and Gafsi (2017) empirically demonstrated the institutional factors and cost of IPSAS adoption to improve the transparency and comparability of financial statements, such as public external funding, the degree of external openness, and the importance of internal public-sector organizations. However, the benefits of IPSAS adoption have not been empirically explored.

As proposed by Mellor (1996), the most direct benefit of accrual-based adoptions is government financial transparency improvement. Further, the government can enhance public trust, internally, and reliance amongst the international community, externally (see Berger, 2018). Specifically, accrual-based IPSAS practices assist as a catalyst for operational and performance management, and provide longterm sustainability information on public finances $(\mathrm{PwC}, 2013)$, thus convincing service recipients (i.e., consumers, communities, and the public) and resource providers (i.e., taxpayers, donors, lenders, etc.) to support government policies (IPSASB, 2016). Regarding intergenerational equity issues, accrualbased IPSAS provides a balanced and transparent perspective on government resources, investments, 
and sovereign debt that complements the nuances of the fiscal outlook in a more comprehensive and comparable manner, according to country investment prospects and potential economic vulnerability (Berger, 2012).

From the perspective of the economics of public finance, the legitimacy of central government depends on how policymakers should necessarily and sufficiently clarify the impact of their policy interventions in the country's economics (Berger, 2012). Musgrave and colleagues defined the openness of government roles in fiscal stewardship and economic sustainability as allocation, redistribution, and stabilization (Musgrave, Musgrave, \& Bird, 1989). The government should strictly define their functions and programs for delivering public services activity when allocating the budget for specific public goods and services (i.e., public roads, network, and infrastructures). Redistribution means that policymakers have a certain strategy to collect public funds (i.e., progressive tax, grants, and charges) and distribute them to society without ignoring the equity. Lastly, the government is accountably issuing fiscal stimuli for stabilization in times of economic slowdown and decline (i.e., blanket guarantee, public debt).

IPSAS statements have overcome the demands for transparency in government policymakers' actions (IFAC, 2012a). Based on the IFRS, IPSAS will match and fit with complex and advanced government intervention schemes. In allocation function, fiscal policy has an incentive effect on economic agents by providing public spending on economic infrastructures with many schemes. For example, capital spending can be financed with common public sector procurements (IPSAS 17) and construction contracts (IPSAS 11). The government can also utilize public-private partnerships (PPP) with service concession arrangements (IPSAS 32) or financial leasing (IPSAS 13) to procure public infrastructures.

Government redistributive function aims to achieve social welfare through non-exchanged revenue transaction schemes (IPSAS 23). The government can impose the collection of public funds such as tax mechanisms - on the public without directly returning any goods and services. IPSAS related to its RMP accommodates revenue transfers from different levels of government (to achieve national fiscal balance), donations, gifts, and goods and services in-kind as characteristics of the public sector.

The stabilization function is the government role in providing sustainability and intergenerational equity implication of allocation and redistribution policies (Robinson, 1998). The government must adjust the operating deficit and maintain public sector net equity via a prudent indebtedness policy (IPSAS 28-30). Reactively, stabilization is government feedback on macroeconomic indicators such as economic growth, unemployment, aggregate consumption and production, and external economic shock. The nature of government intervention schemes must at least meet necessary and sufficient conditions. For example, if the systemic impact of financial institution crisis was met, then the government might prevent it with tactical interventions such as financial asset guarantee or buying an asset to maintain public trust. Further, accrual-based IPSAS provides recording procedures for purchasing financial assets as an investment and periodically evaluates their value (IPSAS 28-30).

In addition, according to harmonization between government accounting and finance statistics (as fiscal transparency reports), the IPSAS Board is earnestly concerned with identifying, managing, and reducing discrepancies (IFAC, 2012b). For example, IPSASB has mapped a chart of accounts and reconciled fiscal accounts between IPSAS and the GFS concept, such as IPSAS net equity vs. GFS net worth, IPSAS surplus/deficit vs. GFS revenue net operating balance, IPSAS vs. GFS revenue expenses, and IPSAS vs. GFS measurement and recognition.

\section{Fiscal transparency measurement}

Fiscal policy transparency indicators are defined as the openness of fiscal accounts in each of the PFM cycles (see De Renzio \& Masud, 2011; Hameed, 2005). The IBP developed the Open Budget Index (OBI) based on PFM best practices of IMF, OECD, and World Bank prescriptions. It indicates the availability, timeliness, and comprehensiveness of (a) formulation of the budget by the executive, (b) budget enactment by the legislative, (c) budget execution by the executive, and (d) year-end reports (Seifert et al., 2013). 
Specifically, the OBI elaborates the existing budgeting process, such as budget preparation (executive budget proposal, pre-budget statement, citizens' budget), and enacts the budget, in-year reports, mid-year review, and year-end report until the audit report. The elements of the budget document contain fiscal information. For example, the budget must disclose revenue compositions, expenditure dimensions, and financing activities. The OBI also highlights the importance of managing fiscal risk, revealing extra-budget, off-budget, and intergovernmental funds, investment in associations, and financial and non-financial assets. All documents must coherently present the budget vs. the actual comparison and its variance analysis. Eventually, the year-end report must be guaranteed by the assurance procedure of the external audit.

Advocating a comparable index across countries and methodological soundness, the IBP conducts primary data questionnaires that are completed by independent researchers in each country and blindly reviewed by two country experts, acquires feedback from government, and makes final decisions scored by the IBP team based on citations and attaches them to relevant documents (De Renzio \& Masud, 2011; IBP, 2012). The IBP has released OBI surveys in 2006, 2008, 2010, 2012, 2015, and 2017 and has been empirically used by several researchers to investigate the determinants of fiscal transparency (see Arapis \& Reitano, 2017; Wehner \& Renzio, 2013) and its impacts (see Blume \& Voigt, 2013; Peat, Svec, \& Wang, 2015).

\section{Accrual-based IPSAS conformity level and central government fiscal transparency}

Enhancing financial transparency has become the tagline for the consequences of the adoption of global accounting standards. In the private sector, several researchers have developed strong arguments and empirically tested the effect of IFRS adoption on improving transparency. Lang and Stice-Lawrence (2015) found that IFRS adoption improves annual reports' disclosure by reducing redundancy and increasing comparability. Li and Yang (2016) and Beattie, Fearnley, and Hines (2012) suggested that IFRS adoption has decreased the complexity of excessive disclosure, thus reflecting the usefulness of annual reports.

In the public sector, financial transparency is conceptually related to the adoption of international accounting standards (see IPSASB, 2016), accrual-based accounting practices (see Mellor, 1996; Robinson, 1998) and more general New Public Management (NPM) best practices (see Galera \& Bolívar, 2007). Accrual-based IPSAS reflects better quality in various dimensions of government reports, such as understandability, comparability, and consistency (IPSASB, 2016). The consistency of financial statements' formats, procedures, and policies will promote better understandability and comparability among entities. Therefore, IPSAS produces a high-quality report that enhances financial informativeness and usefulness for the decision-making process.

There are several kinds of research focusing on empirical evidence of the adoption of global accounting standards on government transparency. Galera and Bolívar (2007) have empirically demonstrated perceptions from National Accounting Standard Setter (NASS) respondents from 47 countries according to the role of IPSAS in promoting NPM postulates, such as improving information transparency, efficiency, and benchmarking analysis. In particular, IPSAS encourages fair value measurement, which is perceived to provide more accurate and complete information, since it considers the current market and economic environment, thus improving the relevancy, understandability, and timeliness of government financial statements. Further, Galera and Bolívar (2011) examined the NASS respondents for OECD and non-OECD countries to demonstrate the positive influence of accrual-based IPSAS on financial transparency.

Bolívar and Galera (2012) subsequently explored the NASS perception of fair-value IPSAS capability in transparency improvement in OECD. The estimation results remained consistent with their previous study, finding that financial transparency supports qualitative aspects (understandability, comparability and timeliness). Galera and Bolívar (2012) went on to empirically test their previous argument in the Spanish context. The same results have suggested that IPSAS supports the transparency and timeliness of financial reporting in a proper public governance environment. 
Some studies limited accrual adoptions to a certain country. By using the Greek municipal context, Cohen (2012) found that accrual accounting improved decision-making by exposing more reliable and transparent presentation of financial indicators. For monitoring fiscal stance, rather than the traditional cash basis, accrual numbers exploited a wide horizon and more clearly exposed the revenue and expense accounts. Other empirical evidence exhibited a positive relationship between the adoption of accrual and efficiencies across German municipalities (Lampe, Hilgers, \& Ihl, 2015). Even though that study was not focused on transparency, it argued that due to higher openness, the efficiency of resource allocation would increase.

According to fiscal transparency, OBI captures the availability, timeliness, and comprehensiveness of three public financial management cycles: (a) budget formulation, (b) budget enactment, (c) budget execution, and (d) year-end reports (Begg, 2014; De Renzio \& Masud, 2011; Heald, 2012). Budget documents should disclose revenue compositions, expenditure dimensions, financing activities, fiscal risk analysis, extra-budget, off-budget, and intergovernmental funds, investment in associations, and financial and non-financial asset. All documents in each stage must be coherently presented between budgets and their actual variances analysed, and the reporting quality should be assured (Seifert et al., 2013).

In accordance with budgetary systems that are mostly on a cash basis (Moretti, 2016), accrualbased IPSAS encourages the disclosure of hidden fiscal transactions in the year-end fiscal report, such as off-budget, extra-budget, and off-balance sheet related entries (IPSASB, 2016). In terms of budgeting, off-budget and extra-budget entries are flow resources that have not passed the normal procedure or are not clearly reflected in budgetary transactions, such as non-cash transactions, pensions, social security, divestments of equities, privatizations, waivers of debt agreements, and other separate accounting entities and transactions. Non-cash transactions that recognize rights and obligations of central government are improperly captured from normal cash-based accounting and budgeting reports. For example, suspense of accounts and arrears of payment are only recognized in financial position and performance statements, not budgetary statements. Off-balance sheet information such as financing of operating leases and contingent liabilities must be appropriately disclosed in the notes of financial statements that are mandated by accrual-based IPSAS. Therefore, a single set accrual-based IPSAS implementation that produces all financial statement reports and pervasive compliance with accounting policies will systematically promote higher fiscal transparency. The following hypothesis statement is:

H1: Higher accrual-based IPSAS level is associated with increased fiscal transparency.

\section{Research Methodology}

\section{Sample selection}

This study utilizes central government financial statements that cover OECD and non-OECD including BRICS - countries. It intends to include as many samples as possible from databases of Word Bank and IMF economic and governance indicators; the OBI surveys only provide 80-100 central governments samples. Using published financial statements and/or accounting policies from the Ministry of Finance website to measure accrual levels, we collected 77 central government reports from 2008 until 2015. The fiscal year 2008 was the start of the global financial crisis, which made central governments decide to execute fiscal policies and commit to PFM initiatives (Berger, 2012), until 2015, the year of the latest financial reports we have populated. In particular, the sample represents 59 nonOECD and 18 OECD countries with a total of 616 observations. However, the estimation model reduces this figure to 511 observations due to incomplete data (see Table 1). 
Table 1

\section{Sample Selections}

\begin{tabular}{lc}
\hline Central government of economic characteristics and governances indicators as initial sample & 201 \\
\hline - Central governments with missing fiscal transparency indicators based on IBP surveys. & $(101)$ \\
- Central governments with missing financial statements, budget reports, accounting standard & $(24)^{*}$ \\
documents for accrual-based IPSAS measurement & $77^{* *}$ \\
\hline Final sample
\end{tabular}

Note. Observations consist of 77 countries including 15 OECD and 5 BRICS countries from 2008 until 2015 fiscal years. * Accrual-based IPSAS measurement results for 616 observations of balanced panels. ** Regression analysis reduced observations of unbalanced panels to 511 .

\section{Measuring accrual-based IPSAS implementation levels}

We have distinguished three measures of IPSAS implementation in previous research. Each proxy type has demonstrated its accomplishment, with some limitations. The first type of identification of accrual is whether the government has the commitment to refer to international based standards. Previous studies have mapped central government accounting practices and simply identified whether IPSAS has been adopted, regardless of whether a cash or accrual basis is used (see Christiaens et al., 2014; Christiaens, Reyniers, \& Rolle, 2010; Sellami \& Gafsi, 2017). The second type of identification of accrual-based government financial statements can be distinguished from main presentations and notes. Pina and Torres (2003) found that accrual transactions were represented in the financial position and financial performance statements. However, it was challenging to distinguish the main presentations between modified accrual and full accrual. Therefore, the accounting policy will precisely show the real entity's revenue and expense recognition of accounting rules (see Appendix A).

The third type of identification is at the level of accounting policies. PwC (2014) has explored the maturity level of European central government accounting practices coherently with IPSAS (see Appendix A). However, by using the European Public Sector Accounting Standards (EPSAS) in the EU, an accrual measure was developed based on accrual-based IPSAS and European System of Accounts (ESA). It comprises recognition, measurement, and presentation policies in IPSAS and also accommodates ESA policies. For example, IPSAS policies do not recognize social security, whereas ESA policies do.

Accrual transactions and timely recognition of revenues and expenses when they are incurred (regardless of cash received for revenues and paid for expenses) creates the full picture of future cash flows, thus enhancing cash management and prediction (Berger, 2018). Based on PwC (2014) measure and IPSAS statements, we develop eight (8) basic accrual accounting policies.

1. Recognition of the non-exchanged transaction (NET) of revenues (i.e., Tax revenue, transfer revenue) reflects the gross amount of fair value (IPSAS 23.48).

2. Exchanged transactions (ET) of revenues (i.e., revenue from sales of goods and services, interest, and dividends) are measured at the net amount of fair value (IPSAS 9.14). Further, disclosing collection management and efforts, the value of receivables or payables must be systematically evaluated for reliability, such as inflating both value and collectability. Thus, the allowance and impairment loss will be considered as a potential deduction of tax revenues (IPSASB, 2016).

3. Inventory policies are also affected by specific characteristics of accrual recordings. The life cycle of inventories in accounting statements recognizes purchased inventories - at the lower of cost and net realizable value or at the lower cost and current replacement cost - in a timely manner with account payables (IPSAS 12.15), and the process of costing of finished goods and transferring to citizens (in certain circumstances, for example, the existing co-payment needs to be recorded as 
revenues and the cost of goods sold as expenses) (IPSAS 12.15). Periodically, inventories are examined for their value to be appropriately impaired (IPSAS 12.44) to transparently expose inventory management (IPSASB, 2016).

4. Property, plant, and equipment (PPE) form the most considerable part of public sector assets in financial position statements. The management of fixed assets is mostly decentralized and requires a register of individual items, periodic inspection, and proper valuation. In accrual principles, the initial acquisition of fixed assets needs to be identified in terms of cost, including any transaction costs, useful life, and residual values for depreciation purposes (IPSAS 17.26-30). The mark-to-market value of fixed assets may necessarily establish the value through revaluation (upward valuation) or impairment loss (downward valuation) (IPSAS 21.14). The public sector recognizes gains or losses related to changes in the value of fixed assets in financial position statements. However, fixed asset public sector accounting policies are different from those in the private sector. In the public sector, systematic consumption - through depreciation - and revaluation of fixed assets are intended for cost allocation purposes; in particular, it is dedicated to the pricing (value for money) of maintenance costs and public services rather than satisfying principles of matching cost against revenue (IPSASB, 2016).

5. The recognition and measurement of employee benefits need specific technical aspects if they are to be correctly presented in the notes of financial statements. Actuarial assessment imposes the amount of employee benefit liabilities at best estimation (IPSAS 25.13). Therefore, accrual recognition of employee benefits requires full disclosure of calculations based on adequate systems.

6. A present obligation arising from past events that potentially causes an outflow of resources should be recognized as a liability. In addition, accrual accounting involves best estimate measurement (including risks and uncertainties) of the present value of the liability required for an uncertain time or amount, and possible commitments that are not probable or not reliably measurable (IPSAS 19.5062). For example, warranty provisions for goods and services expenses for future outflow must be consistently recognized. Less probable (possible) outflow has recognized the contingent liabilities in accounting disclosure, and thus provides complete information on liabilities (IPSASB, 2016).

7. Investments in associations are instruments of public sector intervention in the market to support public interest in the corporation to provide public goods or publicly private goods (Musgrave et al., 1989). The government has to maintain its vote in public financial corporations (PFC), public nonfinancial corporations (PNFC), and government business enterprises (GBE) sector equities to control corporate policies for social welfare (IPSASB, 2016). For governments with minimal market interventions, investment in associations is an instrument of the stability process when it is necessary and sufficiently recognized at cost or equity method (IPSAS 7.12): for example, acquisition in times of financial distress and divestment when the market is stable. Further, changes in ownership should adjust its control level systematically (PSAS 7.12) and also impair its value (PSAS 7.35) when it occurs.

8. Financial liabilities and borrowing costs are the main routines of public sector funding activities. Expansion fiscal policy leads to upward budget deficit, which increases financial support from public debt at cost or fair value (IPSAS 29.8). Appropriate public debt valuation promotes government transparency and credibility. Accrual-based accounting provides a complete liability recording, such as amortization, capitalization, and proper maturity value of discounted public debt for disclosure purpose (IPSASB, 2016). Indeed, comprehensive financial liabilities and the cost of sovereign debt presentation are supported by accrual accounting (Table 2). 
Table 2

\section{List of Accrual-based Transactions (IPSAS Number.Paragraph)}

\begin{tabular}{lllll}
\hline \multicolumn{2}{c}{ Essential accrual transactions } & $\mathrm{R}$ & $\mathrm{M}$ & $\mathrm{P}$ \\
\hline 1 & Non-exchanged Transactions (NET): Revenue, Receivable, and Advanced Receipts & \\
1) & NET Revenue & 23.44 & 23.48 & 23.IG 1-53 \\
2) & NET Revenue receivable & 23.106 & 23.48 & 23.IG 1-53 \\
3) & Liabilities/advanced receipt of NET revenues & 23.66 & 23.55 & 23.IG 1-53 \\
4) & Impairment of NET revenues & 23.IG 43 & &
\end{tabular}

2 Exchanged Transactions (ET): Revenue and Receivable
1) ET Revenue
9.28
9.14
9.IG $1-34$
2) ET Revenue receivable
9.12
9.14
9.IG $1-34$
3) Impairment of ET revenues
9.14
9.IG $1-34$

3 Inventories and Expenses
1) Inventories
12.15
$12.15-43$
2) Cost-of-goods-sold
12.44
12.44
3) Expense
12.44
4) Impairment

4 Property, Plant and Equipment, Depreciation, and Impairment
1) Property, Plant, and Equipment
17.26
17.30
$17.88-94$
2) Depreciation
17.13
3) Impairments

5 Employee Benefit

Short-term employee benefits

6 Provision and Contingent Liabilities
1) Provision
19.22
19.44
2) Contingent Liabilities
19.18
19.18
19.100

7 Investment

1) Investment in Associates

7.11

7.17

7.43-46

2) Revaluations

7.17

36.16

3) Impairments

7.35

4) Reclassifications of Investment

8 Financial Liabilities and Borrowing Cost
1) Financial Liabilities
29.8
29.8
$30.38-39$
2) Borrowing Cost
5.14
5.18
5.BC68

Note. Each recognition $(\mathrm{R})$ - measurement $(\mathrm{M})$, and presentation $(\mathrm{P})$ are scored for conformity: $0=$ does not conform, $0.5=$ partially conforms, and $1=$ fully conforms. Each of eight-transaction sums of scores is scaled by perfect scores. BC: Basis for Conclusions. IG: Implementation Guidance. AG: Application Guidance.

Content analyses of hand-collected financial statements are conducted to achieve reliable scoring of accrual level index measurements. Using ATLAS.ti software, the important phrases, sentences, and paragraphs from financial statement documents are highlighted based on the dimensions (observed 
variables) of the accrual-level construct. Each aspect score depends on subjective judgments of its conformity on accrual-based IPSAS ( $0.5=$ partially conforms and $1=$ fully conforms). For example, IPSAS non-exchanged transactions revenue is measured in terms of the gross amount of increase in the net asset. If central government measures use the gross amount for taxes and the net amount for grants, then this is identified as partially conforming to IPSAS.

The list of basic accrual-based IPSAS transactions is shown in Table 2. Further, the technical validity objective is handled via confirmatory factor analysis (CFA), utilizing the STATA statistical package. This study estimates CFA as pool data with year groups due to the nature of growing accrual adoption year-by-year assumptions. The accrual level latent variable is reliable when the loading factors, as the weight of each dimension and item, are strong. Technically, standardized loading factors between observed variables (dimensions) and observed variables (accrual level latent variable) are $\geq 0.5$ (Hair, Black, Babin, \& Anderson, 2010).

CFA can generate a single set of factor scores for the next research objective: regression analysis. Using multilevel measurement of a second-order latent variable, the accrual level scores (Accrual.Level) are formed by the scores for the accrual commitment (Accrual.Commitment), accrual report (Accrual.Report), and accrual policy (Accrual.Policy) latent variables (see Figure 1).

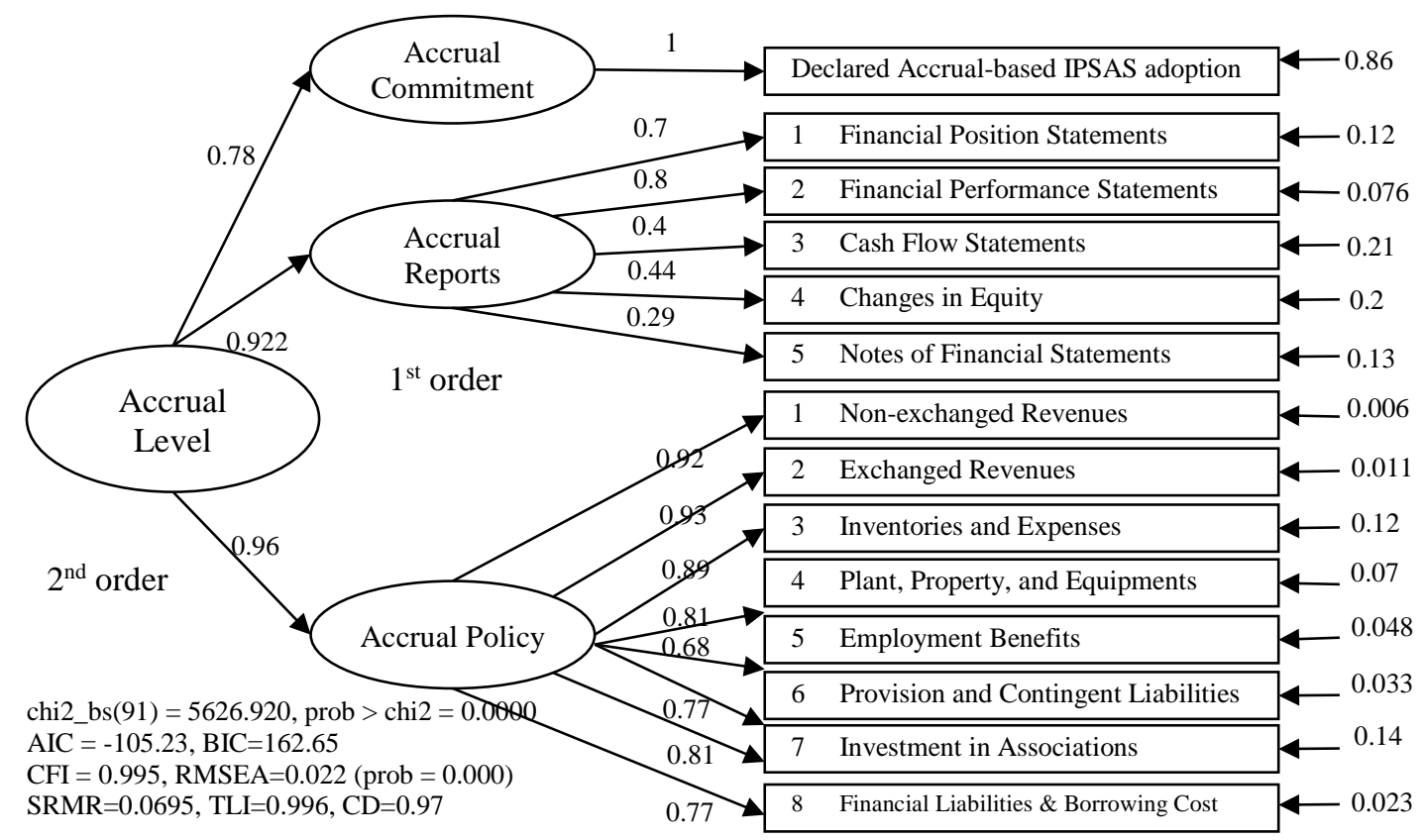

Figure 1. Accrual-based IPSAS Construct and CFA Results

First and second order are estimated simultaneously and grouped by year. Source: authors' calculation.

\section{Research model}

Conducting panel regression estimation and for external validity purposes, this study applies the following research model to test $\mathrm{H} 1$ :

Fiscal.Transp $\mathrm{i}_{\mathrm{i}, \mathrm{t}}=\beta_{0}+\beta_{1}$ Accrual. $(\text { Commitment,Report,Policy,Level })_{\mathrm{i}, \mathrm{t}}+$ $\beta_{2}$ Rule.of.Law $_{\mathrm{i}, \mathrm{t}}+\beta_{3}$ Democ $_{\mathrm{i}, \mathrm{t}}+\beta_{4}$ Debt.per.GDP $\mathrm{i}, \mathrm{t}+\beta_{5}$ GDP.per.Cap ${ }_{\mathrm{i}, \mathrm{t}}+\beta_{6}$ Pop $_{\mathrm{i}, \mathrm{t}}+$ $\beta_{7 \text { is.OECD }}$ i,t $+\varepsilon_{\mathrm{i}, \mathrm{t}}$

As the dependent variable, Fiscal Transparency score (Fiscal.Transp) is based on OBI surveys and ranges from 0 to 100 (IBP, 2008, 2010, 2012, 2015). The main independent variables, accrual-based IPSAS scores, are generated from CFA predictions which result in standardized values of latent variables. There are four constructs (latent) of accrual-based IPSAS levels. The first order of CFA estimation generates factor scores for accrual commitment (Accrual.Commit), accrual report 
(Accrual.Report), and accrual policy (Accrual.Policy). The second order of CFA results from factor scores of total accrual level scores (Accrual.Level). It is expected that accrual-based IPSAS practices will have a positive association with fiscal transparency.

The rule of law (Rule.of.Law) indicates a good public governance environment that represents the quality of government regulation, contract enforcement, law enforcement, and courts (Kaufmann, Kraay, \& Mastruzzi, 2011). The indicators range from -2.5 to 2.5 in units. The demands for fiscal transparency are expected to be driven by better law enforcement and obedience to the legal environment. Based on Arapis and Reitano's (2017) study, the democratization index (Democ) measures democratic system scores from the least democratic (0) to the most democratic (10). Public participation and voice are predicted to be the determinants of fiscal transparency improvement.

Debt per GDP (Debt.per.GDP) reflects demands for transparency. High sovereign debt motivates policymakers to be more transparent to persuade legitimacy. However, previous studies have exhibited reverse results (see Alt \& Lassen, 2006; Bastida, Guillamon, \& Benito, 2015). Excessive debt induces subsequent complex problems such as borrowing cost or the risk of default, thus inspiring elected policymakers to be opaque about the real fiscal stance (Bastida et al., 2015)

GDP per Capita (GDP.per.Cap) is the proxy of citizen's economic welfare. Previous research has exhibited that higher income is associated with high-quality public services and transparent tax usage. Based on legitimacy theory, both GDP per Capita and population represent pressure from citizens for financial information transparency (Bolívar, Muñoz, \& Hernández, 2013).

OECD countries are characterized as having established good public governance practices. The OECD has created a good governance framework and is committed to implementing its principles, such as accountability, transparency, efficiency, effectiveness, responsiveness, and the rule of law (OECD, 2011). See Table 3 for explanations of the independent and dependent variables.

Table 3

Variables, Measures, and Sources

\begin{tabular}{lc}
\hline Variables and Measure & Source(s) \\
\hline
\end{tabular}

Main models:

Fiscal.Transp: Fiscal transparency level based on Open Budget Index https://www.internationalbudget.org (OBI) scores from International Budget Partnership (IBP) surveys. A high score reflects high transparency (0-100)

Accrual.Commitment: Accrual-based IPSAS implementation level. Survey of accrual-based IPSAS commitment to adopt based on PwC (2014), Christiaens et al. (2014), and IPSASB surveys. Explicit or implicit declaration statement in financial statements to refer fully or partially to accrual-based IPSAS implementations. (1=partially or fully refers to accrual-based IPSAS, $0=$ otherwise)

Accrual.Report: Accrual-based IPSAS implementation level. Standardized scores of first order CFA estimation from the five existing financial statement components. Raw scores of each component are dummy variables $(1=$ exists, $0=$ none); $C F A$ prediction results in a standardized value with an average of zero.

Accrual.Policy: Accrual-based IPSAS implementation level. Standardized scores of first order CFA estimation from weighted aggregate scores of eight accrual-based IPSAS policies. Raw scores of eight policy scores are continuous variables (0-1); CFA prediction results in a standardized value with an average of zero.

PwC (2014), Christiaens et al. (2014), IPSASB surveys, or financial statements

Financial statements of each central government publication

Financial statements, budget realization report, accounting standard, or public financial management regulation 
Table 3 (continued)

\begin{tabular}{|c|c|}
\hline Variables and Measure & Source(s) \\
\hline $\begin{array}{c}\text { Accrual.Level: Accrual-based IPSAS implementation level. } \\
\text { Standardized scores of second order CFA estimation from three accrual } \\
\text { level measures: Accrual.Commitment, Accrual.Report, and } \\
\text { Accrual.Policy. CFA prediction results in a standardized value with an } \\
\text { average of zero. }\end{array}$ & $\begin{array}{l}\text { Financial statements, budget } \\
\text { realization report, accounting } \\
\text { standard, or public financial } \\
\text { management regulation }\end{array}$ \\
\hline $\begin{array}{l}\text { Rule.of.Law: Quality of public governance based on law enforcement } \\
\text { and social confidence to abide the rules. Standardized value with ranges } \\
\text { from }-2.5 \text { to } 2.5 \text {. A high value reflects high rule of law. }\end{array}$ & World Bank (n.d.a) \\
\hline $\begin{array}{l}\text { Democ: Quality of public participation based on the Economist } \\
\text { Intelligence Unit's democratization index that ranges from least } \\
\text { democratic (0) to most democratic (10). }\end{array}$ & The Economist Group (n.d.) \\
\hline $\begin{array}{c}\text { Debt.per.GDP: Public finance characteristics. Debt per GDP, scaled by } \\
\text { natural logarithm. }\end{array}$ & World Bank (n.d.b) \\
\hline $\begin{array}{c}\text { GDP.per.Cap: Citizen wealth indicators. GDP per capita, scaled by } \\
\text { natural logarithm. }\end{array}$ & World Bank (n.d.c) \\
\hline $\begin{array}{l}\text { Pop: Demography and public services demands. Country populations } \\
\text { scaled by natural logarithm. }\end{array}$ & World Bank (n.d.d) \\
\hline $\begin{array}{l}\text { is.OECD: OECD membership reflects an established good public- } \\
\text { governance platform. ( } 1=\mathrm{OECD}, 0=\text { otherwise })\end{array}$ & OECD (n.d.) \\
\hline
\end{tabular}

\section{Analysis}

\section{Latent variables for each accrual-based IPSAS level}

Table 4 demonstrates accrual-based IPSAS aggregate scores before performing CFA estimation. More than one-third of central governments in the sample commit to and are intent on accrual-based IPSAS practices: thus, IPSAS has referred to national accounting standards. Most of the central governments publish more financial report elements and disclosures. Particularly, more than half of central governments have considered supplying statements of their financial position and financial performance (see Irwin, 2012). However, central government accrual policies that conform to IPSAS are relatively low compared to financial report publications. Related to Christiaens et al.'s $(2010,2014)$ findings, accrual-based IPSAS policies were not the only reference for accrual practices. Central governments could apply accrual accounting based on domestic GAAP, statistic-based (GFS), or modified IPSAS. 
Table 4

\section{Descriptive Statistics of Accrual-based IPSAS Raw Scores before CFA Estimation}

\begin{tabular}{|c|c|c|c|c|c|c|c|c|c|}
\hline & mean & $\min$ & $\max$ & & mean & SD & $\min$ & med & $\max$ \\
\hline \multicolumn{10}{|l|}{ Accrual-based IPSAS levels: } \\
\hline 1. Accrual Commitment & 0.325 & $\mathbf{0}$ & 1 & 3. Total policy accruals $(\%)$ : & 27.10 & & 2 & 15.8 & 89.1 \\
\hline 2. Financial Report (\%) & 64.40 & 40 & 100 & 3.1. Non-exchanged Trans. & 0.248 & 0.208 & 3.8 & 0.154 & 0.885 \\
\hline 2.1. Financial Position & 0.609 & 0 & 1 & 3.2. Exchanged Revenues Trans. & 0.292 & 0.284 & 6.3 & 0.125 & 1 \\
\hline 2.2. Financial Performance & 0.304 & 0 & 1 & 3.3. Inventories and Expenses & 0.295 & 0.241 & 0 & 0.188 & 0.875 \\
\hline 2.3. Changes in Equity & 0.525 & 0 & 1 & 3.4. Fixed Assets & 0.349 & 0.347 & 0 & 0.231 & 0.923 \\
\hline 2.4. Cash Flow & 0.548 & 1 & 1 & 3.5. Employment Benefits & 0.198 & 0.301 & 0 & 0 & 1 \\
\hline \multirow[t]{4}{*}{ 2.5. Notes of Financial Statement } & 0.824 & 1 & 1 & 3.6. Provision and Cont. Liab. & 0.181 & 0.244 & 0 & 0.071 & 1 \\
\hline & & & & 3.7. Investment in Associations & 0.153 & 0.200 & 0 & 0.063 & 0.75 \\
\hline & & & & 3.8. Finance. Liab. \& Borrow. Cost & 0.263 & 0.238 & 0 & 0.214 & 1 \\
\hline & & & & Obs. & 616 & & & & \\
\hline
\end{tabular}

Note. All observed variables are scaled by perfect scores ( 1 or 100 for percentages). Source: authors' calculation.

Figure 1 exhibits the CFA model for accrual-level latent variable measurements. The first order of latent variables, Accrual.Commitment, represents a dummy score of declared accrual-based IPSAS implementations. The Accrual.Report reflects strong latent unobserved variables from standardized loading factors of observed variables, except for changes in equity $(0.4<0.5)$, cash flow statements $(0.44<0.5)$, and notes of financial statements $(0.29<0.50)$. The Accrual Policy shows strong reliability and importance of the accrual level measurement, indicated by higher standardized loading factors $(>0.5)$.

The second order of latent variable is developed from three types of accrual level construct variables. The Accrual.Policy latent variable is the most reflective (0.96) to form an accrual level variable. All latent variables have relative importance and significance to form accrual level variables with higher standardized loading factors $(>0.5)$. Therefore, the accrual level construct is reliable as an accrual measure.

Generally, in CFA, a good and fit model is indicated by a strong Comparative Fit Index (CFI) $(0.995 \geq 0.9)$, Tucker-Lewis Index (TLI) $(0.996 \geq 0.95)$, Coefficient Determinant (CD) $(0.970$ closer to 1), and significant Root Mean Square Error of Approximation (RMSEA) $(0.022 \leq 0.08)$, relatively small value of Akaike's information criterion (AIC) and Bayesian information criterion (BIC), with some notes. The significant value of baseline vs. saturated Chi-squared (prob of chi2_bs < 0.05) and Standardized Root Mean Square Residual SRMR (0.069>0.05) indicates improper goodness and fit. However, good and fit CFA model indicators dominate the results. Therefore, for measurement purposes, the predicted latent variables from loading scores of accrual level measures are feasible, with some notices and limitations.

According to Accrual.Report, central government financial performance statements are strong indicators of accrual level compared to other statements. Full accrual adoption produces financial performance statements to report a clean surplus of net equity in financial positions. Non-full accrual statements still allow publishing of financial position statements to report assets and liabilities in parallel. Interestingly, statements of changes in equity were not correlated with accrual level. From this we can conclude that this report format is not critical for central government because the nature of equity belongs to public ownership. Cash flow and notes on the financial statements also did not vary among the samples, thus producing lower scores for loading factor values. 
The Accrual.Policy measure represents the accrual-based IPSAS conformity of accounting policies. Accounting policies of non-exchanged revenues, exchanged revenues, inventories and expenses, and PPE, respectively, have significant importance to accrual level measurement. These types of transactions are highly connected with the core activities of central governments. Revenues and expenses are closely related to budgetary revenues and expenditures. Modifying the accrual numbers of budgetary transactions will produce financial performance statements; thus, the policy of revenue and expenses scored a higher value.

Governments are making greater efforts to comply with PPE accrual policy (Table 4), in that the majority of the developed countries have disclosed land, buildings, and infrastructure assets, as found by Moretti (2016). On the other hand, (a) exchange and (b) non-exchange revenues, and (c) inventories and expenses transactions have a moderate mean percentage of compliance. However, these three kinds of transactions have a higher impact in constructing accrual level. The nature of these clean surplus transactions has leveraged their important accrual recording expertise. Obviously, every accrual transaction that produces both financial performance and position statements will represent higher-level accrual adoptions.

Each of the eight accrual policies captures a mean percentage of IPSAS statement compliance yearly. The plant, property, and equipment (PPE) show the highest percentage among policies. Thus, the accrual policies whose expertise should be increased are: (a) employee benefits, (b) provision, (c) financial instruments (liabilities), and (d) investment in associations. The recording skills of these particular transactions are related to RMP procedures in the accounting disclosure paragraph to be described comprehensively in main presentations. Related to fiscal sustainability, these government intervention instruments involve openness of procedures. For example, provision and contingent liabilities have short-term and long-term consequences on budgetary decisions. Hidden information on liabilities creates unreliable accrual deficit and raises intergenerational equity problems. Therefore, the completeness of off-balance-sheet and off-budget disclosures assists with decision-making for public funding policy (i.e., taxations vs. debts).

\section{Descriptive statistics and correlation matrix}

Table 5 presents descriptive statistics for the regression model variables. Samples consist of a small number of OECD countries (23\%). The rest of the accrual level variables are normally spread and generated from CFA loading factor scores. Generally, all variables are normally distributed, except for Debt per GDP in terms of heterogeneity of cross-country characteristics, since few OECD countries have high debt per GDP. Democratization is achieved by most countries. Most central governments have scored more than 50 on performing fiscal transparency. However, the accrual practices are relatively dominated by quite low levels compared to the fiscal transparency pattern, which has similar sample characteristics to the rule of law, GDP per Capita, and population, in that the lower indicator is owned tolerably by most countries.

Table 5

Descriptive Statistics of Independent and Dependent Variables

\begin{tabular}{lrrrrrr}
\hline & \multicolumn{1}{c}{ Mean } & \multicolumn{1}{c}{ SD } & \multicolumn{1}{c}{ min } & \multicolumn{1}{c}{ median } & \multicolumn{1}{c}{ max } & \multicolumn{1}{c}{ skew. } \\
\hline Fiscal.Transp (0-100) & 50.352 & 20.334 & 0.728 & 50.685 & 93.163 & -0.233 \\
Accrual.Commitment (=1) & 0.329 & 0.470 & 0.000 & 0.000 & 1.000 & 0.729 \\
Accrual.Report & 0.050 & 0.338 & -0.384 & -0.050 & 0.813 & 0.643 \\
Accrual.Policy & 0.029 & 0.190 & -0.197 & -0.059 & 0.561 & 1.005 \\
Accrual.Level & 0.001 & 0.352 & -0.426 & -0.155 & 0.91 & 0.866 \\
\hline & & & & & & \multicolumn{3}{c}{ Continues }
\end{tabular}


Table 5 (continued)

\begin{tabular}{lrrrrrr}
\hline & Mean & SD & min & median & max & skew. \\
\hline Rule.of.Law [(-2.5)-2.5] & -0.031 & 0.830 & -1.265 & -0.231 & 2.045 & 0.981 \\
Democ (0-10) & 6.920 & 3.132 & 0.000 & 8.000 & 10.000 & -1.016 \\
Debt.per.GDP (ln) & 5.697 & 0.235 & 1.983 & 5.654 & 6.079 & -9.568 \\
GDP.per.Cap. (ln) & 11.285 & 2.411 & 5.274 & 10.782 & 17.371 & 0.539 \\
Pop (ln) & 3.062 & 1.484 & 0.275 & 3.008 & 7.226 & 0.417 \\
is.OECD (=1) & 0.231 & & & & & 1.277 \\
\hline Obs. & 511 & & & & &
\end{tabular}

Note. Source: authors' calculation.

In particular, high scores for the accrual policy measure have been achieved and established by most OECD countries (i.e., New Zealand, the UK, and the US) and partly developed countries in Asia (i.e., Thailand) and Latin America (Costa Rica). In contrast, most developing countries in Africa (i.e., Angola, Egypt, and Burkina Faso) and Asia (i.e., Cambodia and Vietnam) have low scores for accrual policy. However, efforts to persuade modern accounting practices have been accomplished by various characteristics of central governments, as indicated by the high growth of conformity in accrual-based IPSAS policies (i.e., Dominican Republic, Indonesia, Philippines, Turkey, France, South Africa, Slovenia, Portugal, Brazil, and Poland) (see Appendix A).

Table 6

\section{Correlation Matrix}

\begin{tabular}{|c|c|c|c|c|c|c|c|c|c|c|c|c|}
\hline & & 1 & 2 & 3 & 4 & 5 & 6 & 7 & 8 & 9 & 10 & 11 \\
\hline 1 & Fiscal.Transp (0-100) & 1.00 & & & & & & & & & & \\
\hline 2 & Accrual.Commitment & $0.31^{* * *}$ & 1.00 & & & & & & & & & \\
\hline 3 & Accrual.Report & $0.53^{* * *}$ & $0.77^{* * *}$ & 1.00 & & & & & & & & \\
\hline 4 & Accrual.Policy & $0.58^{* * * *}$ & $0.77^{* * *}$ & $0.95^{* * * *}$ & 1.00 & & & & & & & \\
\hline 5 & Accrual.Level & $0.56^{* * *}$ & $0.82^{* * * *}$ & $0.98^{* * *}$ & $0.99^{* * * *}$ & 1.00 & & & & & & \\
\hline 6 & Rule.of.Law [(-2.5)-2.5] & $10.66^{* * *}$ & $0.34^{* * *}$ & $0.50^{* * * *}$ & $0.62^{* * *}$ & $0.58^{* * *}$ & 1.00 & & & & & \\
\hline 7 & Democ (0-10) & $0.54^{* * *}$ & $0.31^{* * *}$ & $0.54^{* * *}$ & $0.52^{* * *}$ & $0.52^{* * *}$ & $0.50^{* * * *}$ & 1.00 & & & & \\
\hline 8 & Debt.per.GDP (ln) & $-0.12^{* *}$ & $-0.12^{* *}$ & -0.06 & -0.07 & -0.07 & $-0.15^{* * *}$ & $*-0.02$ & 1.00 & & & \\
\hline 9 & GDP.per.Cap. (ln) & -0.01 & 0.02 & 0.03 & 0.07 & 0.05 & 0.04 & -0.01 & $-0.11^{* *}$ & 1.00 & & \\
\hline 10 & Pop (ln) & 0.04 & $-0.11^{* *}$ & 0.01 & 0.05 & 0.02 & -0.07 & $-0.24^{* * *}$ & $* 0.13^{* *}$ & 0.01 & 1.00 & \\
\hline 11 & is. $\mathrm{OECD}(=1)$ & $0.54^{* * *}$ & $0.35^{* * *}$ & $0.51^{* * * *}$ & $0.60^{* * *}$ & $0.57^{* * *}$ & $0.82^{* * *}$ & $0.48^{* * * *}$ & -0.05 & -0.02 & 0.04 & 1.00 \\
\hline
\end{tabular}

Note. ${ }^{*} \mathrm{p}<.10 .{ }^{* *} \mathrm{p}<.05 .{ }^{* * *} \mathrm{p}<.001$. Source: authors' calculation.

Table 6 exhibits the bivariate correlation matrix between variables. In general, all variables are positively correlated with fiscal transparency except for debt per GDP (significantly negative), GDP per capita (insignificant), and Population (insignificant). A higher debt per GDP that is associated with lower fiscal transparency is indicative of problematic governance of public debt policy (Bastida et al., 2015). At the same time, a lower GDP per capita motivates more openness. High accrual implementations of OECD countries are relatively consistent with openness of fiscal information (i.e., New Zealand, the UK, and the US). Low accrual practices are also coherent with the opaque government financial information in developing countries (i.e., Angola, Burkina Faso, and Cambodia). However, this one-byone relationship does not feasibly allow testing a strong associative and causative hypothesis with 
multiple variables. Therefore, we conducted an estimation of the regression model to infer a reliable causative relationship and for external validity purposes (see Appendix A).

\section{Regression results}

We conducted random-effects GLS regression to estimate four models of panel data, since a null hypothesis is not rejected in the Hausman test. Accrual levels in most cases are positively associated with fiscal transparency (Table 6). However, simple accrual-level measurement (Accrual.Commitment) is not significantly associated with fiscal transparency. This is not surprising, since most central governments are permitted to explicitly or implicitly implement accrual practices based on IPSAS.

Generally, accrual measures in the Accrual Report, Policy, and Level (comprehensive) models have a positive relationship with fiscal transparency (H1 is accepted). Although the Accrual.Report measure indicates a simple and reliable variable for the tested hypothesis, this existence-based financial statement element measurement type still has several disadvantages, such as weakness of some representative observed variables (i.e., cash flow, changes in equity, and notes) (see Figure 1).

According to the fiscal transparency objective, the evidence suggests that implicit accrual-based IPSAS implementation affects the openness of central government fiscal policy interventions (Berger, 2012; IFAC, 2012a; IPSASB, 2016). Prominent accrual-based transactions produce comprehensive and high-quality financial statements, particularly interrelated financial performance and position statements. Accrual accounting policies trigger a better procedural RMP of rights and obligations that supports transparency behaviour.

Table 7

\section{Regression Results}

\begin{tabular}{|c|c|c|c|c|c|c|c|c|c|}
\hline \multirow[t]{2}{*}{ Fiscal.Transp (0-100) } & \multicolumn{3}{|c|}{$\begin{array}{c}\text { Accrual Commitment } \\
\text { Model }\end{array}$} & \multicolumn{2}{|c|}{$\begin{array}{l}\text { Accrual Report } \\
\text { model }\end{array}$} & \multicolumn{2}{|c|}{$\begin{array}{l}\text { Accrual Policy } \\
\text { model }\end{array}$} & \multicolumn{2}{|c|}{$\begin{array}{l}\text { Accrual Level } \\
\text { model }\end{array}$} \\
\hline & & Coef. & t-stat & Coef. & t-stat & Coef. & t-stat & Coef. & t-stat \\
\hline Accrual.Commitment & + & 3.849 & {$[1.643]$} & & & & & & \\
\hline Accrual.Report & + & & & 8.51 & {$[2.469] * *$} & & & & \\
\hline Accrual.Policy & + & & & & & 14.817 & {$[2.333] * *$} & & \\
\hline Accrual.Level & + & & & & & & & 8.436 & {$[2.501] * *$} \\
\hline Rule of Law & + & 13.409 & {$[4.182] * * *$} & 12.652 & {$[3.859] * * *$} & 12.219 & {$[3.688] * * *$} & 12.329 & {$[3.716] * * *$} \\
\hline Democ & + & 1.828 & {$[3.302] * * *$} & 1.733 & {$[3.292] * * *$} & 1.77 & {$[3.340] * * *$} & 1.75 & {$[3.324] * * *$} \\
\hline Debt per GDP & $+/-$ & -0.475 & {$[-0.510]$} & -0.165 & {$[-0.162]$} & -0.642 & {$[-0.635]$} & -0.377 & {$[-0.371]$} \\
\hline GDP per Cap & + & -0.598 & {$[-1.071]$} & -0.632 & {$[-1.157]$} & -0.68 & {$[-1.235]$} & -0.663 & {$[-1.203]$} \\
\hline Populations & + & 2.373 & {$[2.049] * *$} & 2.099 & {$[1.868]^{*}$} & 2.055 & {$[1.829] *$} & 2.075 & {$[1.852]^{*}$} \\
\hline OECD & + & -4.625 & {$[-1.366]$} & -4.558 & {$[-1.307]$} & -4.661 & {$[-1.334]$} & -4.789 & {$[-1.386]$} \\
\hline Constant & & 40.244 & {$[4.201] * * *$} & 41.558 & {$[4.416] * * *$} & 44.736 & {$[4.730] * * *$} & 43.139 & {$[4.556] * * *$} \\
\hline Obs. & & $511 *$ & $* * *$ & $511^{\circ}$ & $* * *$ & $511^{2}$ & & $511 *$ & $* * *$ \\
\hline $\mathrm{R}^{2}$ overall & & 0.524 & & 0.538 & & 0.539 & & 0.538 & \\
\hline $\mathrm{Chi}^{2}$ & & 154.27 * & $* * *$ & $160.40^{\circ}$ & $* * *$ & 164.33 & $* * *$ & 166.03 * & $* * *$ \\
\hline
\end{tabular}

Note. The null hypothesis is not rejected in the Hausman test; thus all models are estimated by random effect. Source: authors' calculation. $* \mathrm{p}<.10 . * * \mathrm{p}<.05 . * * * \mathrm{p}<.001$.

Related to control variables, respect of the rule of law is positively associated with fiscal transparency. It reflects that good governance indicators of law enforcement and institutional 
arrangements have contributed significant fiscal transparency. Coherently, democratic culture with political competition supports central governments disclosing more fiscal policies. In addition, large populations reflect citizens' desires, which impose consequences in terms of greater demand for public financial transparency. According to institutional theory, accrual-based IPSAS is supported by a better climate of good governance and democracy (see Sellami \& Gafsi, 2017).

However, fiscal indicators (debt per GDP) and wealth indicators (GDP per capita) are not immediately associated with a culture of openness in central government (see Bastida et al., 2015). Actually, this phenomenon is not paradoxical, considering that developed countries with a large ratio of debt per GDP and large GDP per capita have reached a steady stage in fiscal transparency. On the other hand, developing countries aggressively try to catch up with developed countries in terms of fiscal transparency. In addition, the insignificant coefficient for OECD countries seems to imply that PFM reforms in terms of modernizing public sector accounting can be performed by any country in conjunction with better governance. Therefore, the magnitude of changes toward improvement is less pronounced for developed countries.

\section{Conclusions and Recommendations}

This study aimed to explore government accrual-based IPSAS implementation level measurement for a sample of 77 central governments from 2008 to 2015. Generally, the accrual-policies-based measure is better represented than other measures regarding a good and fit model of CFA comprehensive measurement. Accounting policies, specifically in (a) exchanged revenues, (b) non-exchanged revenues, (c) inventories and expenses transactions, capture the intrinsic level of accrual adoptions. These operating transaction types play a major role in forming the most important element of the accrual accounting report: the financial performance statement. The rest of the essential accrual policies show an important characteristic of accrual transactions, particularly in accounting disclosures. However, relatively low compliance needs technical expertise to reduce potential off-balance-sheet and off-budget transactions, such as: employment benefits, provision and contingent liabilities, and financial liabilities and borrowing costs.

This study also aimed to test the empirical model of a positive association between accrual-based IPSAS implementation level and fiscal transparency. Based on 511 observations, the estimation results exhibited positive associations in most cases. However, the simple IPSAS commitment measure is less strongly associated with fiscal transparency. This result is interpreted to mean that accrual accounting has not always been taken based on IPSAS even though de facto accrual-based IPSAS has been referenced by central governments worldwide. Moreover, accrual-based financial statements that support rich fiscal information are only represented by financial performance and position statements. Accrual-based IPSAS implementation improves transparency on the availability of a single set of highquality accounting system procedures to produce comprehensive, relevant, timely, and reliable fiscal information (IFAC, 2012a).

The evidence also suggests that central governments are on the right track to internalize fiscal transparency through accrual-based accounting policies. Implementation of accrual-based accounting, either implicitly or explicitly, on IPSAS will strengthen the fiscal transparency objective when it prioritises prominent accrual accounting policies over clear commitment (PwC, 2013) and the completeness of reports (format). Therefore, the principle of substance over form of high-quality accrual-based IPSAS implementation can be realized when both policymakers and national standardsetters consider bringing their accounting practices in line with the international standard of accrual policies.

This study has several limitations, especially regarding the measurement of accrual levels. Several accounting policies have not been considered, such as a consolidated method of financial statements, non-exchanged expense transactions, and social benefits: there are thus opportunities for future research. 
Fiscal transparency also needs to be elaborated for further analysis. The OBI survey has disaggregation dimensions that have not yet been investigated in detail. Future research should include an in-depth analysis of fiscal transparency variables by disaggregating these variables into dimensions. This would enrich the explanation of the relationship between accrual-based IPSAS levels and fiscal transparency elements.

\section{Contributions}

1st author: Introduction, literature review and hypothesis development, research methodology, analysis, conclusion and recommendation.

2nd author: Literature review and hypothesis development.

3rd author: Research methodology.

4th author: Research methodology.

\section{References}

Alt, J. E., \& Lassen, D. D. (2006). Fiscal transparency, political parties, and debt in OECD countries. $\begin{array}{llll}\text { European Economic } & \text { Review, }\end{array}$ https://doi.org/10.1016/j.euroecorev.2005.04.001

Alt, J. E., Lassen, D. D., \& Skilling, D. (2002). Fiscal transparency, gubernatorial approval, and the scale of government: Evidence from the States. State Politics \& Policy Quarterly, 2(3), 230-250. https://doi.org/10.1177/153244000200200302

Arapis, T., \& Reitano, V. (2017). Examining the evolution of cross-national fiscal transparency. The American Review of Public Administration, 17(5), 643-660. https://doi.org/10.1177/0275074017706740

Baber, W. R., \& Sen, P. K. (1984). The role of generally accepted reporting methods in the public sector: An empirical test. Journal of Accounting and Public Policy, 3(2), 91-106. http://doi.org/10.1016/0278-4254(84)90002-4

Bastida, F., Guillamón, M.-D., \& Benito, B. (2015). Fiscal transparency and the cost of sovereign debt. International Review of Administrative Sciences, 83(1), 106-128. https://doi.org/10.1177/0020852315574999

Beattie, V., Fearnley, S., \& Hines, T. (2012). Reaching key financial reporting decisions: How directors and auditors interact. Accounting Review, 87(5), 1819-1820. https://doi.org/10.1080/17449480.2013.834742

Begg, I. (2014). Fiscal policy transparency. In J. Forssbæck \& L. Oxelheim (Eds.), The Oxford handbook of economic and institutional transparency (pp. 98-115). New York: Oxford University Press.

Benito, B., Brusca, I., \& Montesinos, V. (2007). The harmonization of government financial information systems: The role of the IPSASs. International Review of Administrative Sciences, 73(2), 293317. https://doi.org/10.1177/0020852307078424

Berger, T. M.-M. (2012). Impact of the global financial crisis and the sovereign debt crisis on public sector accounting. In T. M.-M. Berger, IPSAS Explained (pp. 38-50). West Sussex, UK: John Wiley \& Sons, Inc. 
Berger, T. M.-M. (2018). IPSAS explained: A summary of international public sector accounting standards (3rd ed.). West Sussex, UK: Wiley Online Library.

Blume, L., \& Voigt, S. (2013). The economic effects of constitutional budget institutions. European Journal of Political Economy, 29, 236-251. https://doi.org/10.1016/j.ejpoleco.2012.10.004

Bolívar, M. P. R., \& Galera, A. N. (2012). The role of fair value accounting in promoting government accountability. Abacus, 48(3), 348-386. https://doi.org/10.1111/j.1467-6281.2011.00352.x

Bolívar, M. P. R., Muñoz, L. A., \& Hernández, A. M. L. (2013). Determinants of financial transparency in government. International Public Management Journal, 16(4), 557-602. https://doi.org/10.1080/10967494.2013.849169

Chan, J. L., \& Xu, Y. (2012). How much red ink? World Economics, 13(1), 65-74. Retrieved from https://www.worldeconomics.com/Journal/Papers/How\%20Much\%20Red\%20Ink.details?ID=507

Chan, J. L., \& Zhang, Q. (2013). Government accounting standards and policies. In R. Allen, R. Hemming, \& B. H. Potter (Eds.), The international handbook of public financial management (pp. 742-766). London: Palgrave Macmillan UK.

Christiaens, J. R., Reyniers, B., \& Rolle, C. (2010). Impact of IPSAS on reforming governmental financial information systems: A comparative study. International Review of Administrative Sciences, 76(3), 537-554. https://doi.org/10.1177/0020852310372449

Christiaens, J. R., Vanhee, C., Manes-Rossi, F., Aversano, N., \& Cauwenberge, P. van (2014). The effect of IPSAS on reforming governmental financial reporting: An international comparison. International Review of Administrative Sciences, 81(1), 158-177. https://doi.org/10.1177/0020852314546580

Cicatiello, L., De Simone, E., \& Gaeta, G. L. (2017). Political determinants of fiscal transparency: A panel data empirical investigation. Economics of Governance, 18(4), 315-336. https://doi.org/10.1007/s10101-017-0192-x

Cohen, S. (2012). Cash versus accrual accounting measures in Greek municipalities: Proxies or not for decision-making? International Journal of Accounting, Auditing and Performance Evaluation, 8(3), 203. https://doi.org/10.1504/ijaape.2012.047807

Copley, P. A. (1991). The association between municipal disclosure practices and audit quality. Journal of Accounting and Public Policy, 10(4), 245-266. https://doi.org/10.1016/0278-4254(91)90001-z

De Renzio, P., \& Masud, H. (2011). Measuring and promoting budget transparency: The open budget index as a research and advocacy tool. Governance, 24(3), 607-616. https://doi.org/10.1111/j.1468-0491.2011.01539.x

Debrun, X., \& Kumar, M. S. (2007). The discipline-enhancing role of fiscal institutions: Theory and empirical evidence [IMF Working Papers, WP/07/171]. International Monetary Fund. https://doi.org/10.5089/9781451867350.001

Diamond, J. (2002). Performance budgeting is accrual accounting required? [IMF Working Papers, WP/02/240]. International Monetary Fund. Retrieved from https://www.imf.org/external/pubs/ft/wp/2002/wp02240.pdf

Ernst and Young. (2012, September). International public sector accounting standard's disclosure cheklist. Retrieved from https://www.ey.com/Publication/vwLUAssets/EY__International_Public_Sector_Accounting_Standards_Disclosure_Checklist_-

_September_2012_Edition/\$FILE/EY-IPSAS-Ctools-\%20Disclosurechecklist-Sept2012.pdf 
Galera, A. N., \& Bolívar, M. P. R. (2007). The contribution of international accounting standards to implementing NPM in developing and developed countries. Public Administration and Development, 27(5), 413-425. https://doi.org/10.1002/pad.470

Galera, A. N., \& Bolívar, M. P. R. (2010). Can government accountability be enhanced with international financial reporting standards? Public Money and Management, 30(6), 379-384. https://doi.org/10.1080/09540962.2010.525009

Galera, A. N., \& Bolívar, M. P. R. (2011). Modernizing governments in transitional and emerging economies through financial reporting based on international standards. International Review of Administrative Sciences, 77(3), 609-640. https://doi.org/10.1177/0020852311407365

Galera, A. N., \& Bolívar, M. P. R. (2012). Adopting IPSAS to improve governmental accountability in Spain: an empirical study. International Journal of Critical Accounting, 4(5/6), 572-607. https://doi.org/10.1504/ijca.2012.051465

Giosi, A., Brunelli, S., \& Caiffa, M. (2015). Do accrual numbers really affect the financial market? An empirical analysis of ESA accounts across the EU. International Journal of Public Administration, 38(4), 297-310. https://doi.org/10.1080/01900692.2015.999591

Greenwood, D. T. (2018). Moving beyond traditional indicators of fiscal sustainability: Examples from locally chosen indicators. In D. V. Malito, G. Umbach, \& N. Bhuta (Eds.), The Palgrave handbook of indicators in global governance (pp. 325-347). Cham: Springer International Publishing.

Guillamón, M.-D., Bastida, F., \& Benito, B. (2011). The determinants of local government's financial transparency. Local Government Studies, 37(4), 391-406. https://doi.org/10.1080/03003930.2011.588704

Guthrie, J. (1998). Application of accrual accounting in the Australian public sector - rhetoric or reality. Financial Accountability and Management, 14(1), 1-19. https://doi.org/10.1111/14680408.00047

Hair, J., Black, W., Babin, B., \& Anderson, R. (2010). Multivariate data analysis. Upper Saddle River, NJ: Prentice-Hall, Inc.

Hameed, F. (2005). Fiscal transparency and economic outcomes [IMF Working Papers, WP/075/225]. International Monetary Fund. Retrieved from https://www.imf.org/external/pubs/ft/wp/2005/wp05225.pdf

Heald, D. (2012). Why is transparency about public expenditure so elusive? International Review of Administrative Sciences, 78(1), 30-49. https://doi.org/10.1177/0020852311429931

Hyndman, N., \& Connolly, C. (2011). Accruals accounting in the public sector: A road not always taken. Management Accounting Research, 22(1), 36-45. https://doi.org/10.1016/j.mar.2010.10.008

International Budget Partnership. (2008). The open budget survey 2008. Retrieved from https://www.internationalbudget.org/wp-

content/uploads/2011/06/2008FinalFullReportEnglish1.pdf

International Budget Partnership. (2010). The open budget survey 2010. Retrieved from https://www.internationalbudget.org/wp-content/uploads/2011/06/2010_Full_Report-

English.pdf

International Budget Partnership. (2012). Open budget survey methodology. Retrieved from http://www.internationalbudget.org/publications/obi-methodology-201-english-2/ 
International Budget Partnership. (2015). Open budget survey 2015. Retrieved from http://www.internationalbudget.org/wp-content/uploads/OBS2015-Report-English.pdf

International Federation of Accountants. (2012b, October). IPSASs and government - Finance statistics reporting guidelines. Retrieved from https://www.ifac.org/system/files/publications/files/IPSASs and GFS Guidelines FINAL October 16 2012.pdf

International Federation of Accountants. (2012a). Public sector financial management transparency and accountability: The use of international public sector accounting standards. New York, NY: Author.

International Federation of Accountants. (2014, April). The importance of accrual-based financial reporting in the public sector. Retrieved from https://www.ifac.org/system/files/uploads/IPSASB/IPSASB-The-Importance-of-Accrual-basedFinancial-Reporting.pdf

International Monetary Fund. (2012, August 7). Fiscal transparency, accountability and risk. Retrieved from http://www.imf.org/external/np/pp/eng/2012/080712.pdf

International Public Sector Accounting Standards Board. (2013). Reporting on the long-term sustainability of public finances, recommended practice guideline (RPG). Retrieved from https://www.ifac.org/publications-resources/recommended-practice-guideline-reporting-longterm-sustainability-public-sect

International Public Sector Accounting Standards Board. (2016). Handbook of international public sector accounting pronouncements. New York, NY: Author.

Irwin, T. C. (2012, March 28). Accounting devices and fiscal illusions (Staff Discussion Notes No. 12/02). Retrieved from https://www.imf.org/en/Publications/Staff-DiscussionNotes/Issues/2016/12/31/Accounting-Devices-and-Fiscal-Illusions-25795

Kaufmann, D., Kraay, A., \& Mastruzzi, M. (2011). The worldwide governance indicators: methodology and analytical issues. Hague Journal on the Rule of Law, 3(2), 220-246. https://doi.org/10.1017/S1876404511200046

Lampe, L. W., Hilgers, D., \& Ihl, C. (2015). Does accrual accounting improve municipalities' efficiency? Evidence from Germany. Applied Economics, 47(41), 4349-4363. https://doi.org/10.1080/00036846.2015.1030562

Lang, M. H., \& Stice-Lawrence, L. (2015). Textual analysis and international financial reporting: Large sample evidence. Journal of Accounting and Economics, 60(2-3), 110-135. https://doi.org/10.1016/j.jacceco.2015.09.002

Lapsley, I., Mussari, R., \& Paulsson, G. (2009). On the adoption of accrual accounting in the public sector: A self-evident and problematic reform. European Accounting Review, 18(4), 719-723. https://doi.org/10.1080/09638180903334960

Li, X., \& Yang, H. I. (2016). Mandatory financial reporting and voluntary disclosure: The effect of mandatory IFRS adoption on management forecasts. The Accounting Review, 91(3), 933-953. http://doi.org/10.2308/accr-51296

Luder, K. (2000). National accounting, governmental accounting and cross-country comparisons of government financial condition. Financial Accountability and Management, 16(2), 117-128. https://doi.org/10.1111/1468-0408.00100

Martí, C., \& Kasperskaya, Y. (2015). Public financial management systems and countries' governance: A cross-country study. Public Administration and Development, 35(3), 165-178. https://doi.org/10.1002/pad.1711 
Mellor, T. (1996). Why governments should produce balance sheets. Australian Journal of Public Administration, 55(1), 78-81. https://doi.org/10.1111/j.1467-8500.1996.tb01184.x

Moretti, D. (2016). Accrual practices and reform experiences in OECD countries results of the 2016 OECD accruals survey. OECD Journal on Budgeting, 16(1), 9-28. https://doi.org/10.1787/budget-16-5jlv2jx2mtzq

Musgrave, R. A., Musgrave, P. B., \& Bird, R. M. (1989). Public finance in theory and practice. New York: McGraw-Hill.

Organisation for Economic Co-operation and Development. (2011). Public governance. Retrieved from http://www.oecd.org/investment/toolkit/policyareas/publicgovernance/41890394.pdf

Organisation for Economic Co-operation and Development. (n.d.). List of OECD member countries Ratification of the convention on the OECD. Retrieved from http://www.oecd.org/about/membersandpartners/list-oecd-member-countries.htm

Peat, M., Svec, J., \& Wang, J. (2015). The effects of fiscal opacity on sovereign credit spreads. Emerging Markets Review, 24(September), 34-45. https://doi.org/10.1016/j.ememar.2015.05.001

Pina, V., \& Torres, L. (2003). Reshaping public sector accounting: An international comparative view. Canadian Journal of Administrative Sciences, 20(4), 334-350. https://doi.org/10.1111/j.19364490.2003.tb00709.x

PricewaterhouseCoopers. (2013, April). Towards a new era in government accounting and reporting. Retrieved from https://www.pwc.com/gx/en/psrc/publications/assets/pwc-global--ipsas-surveygovernment-accounting-and-reporting-pdf.pdf

PricewaterhouseCoopers. (2014, August 1). Collection of information related to the potential impact, including costs, of implementing accrual accounting in the public sector and technical analysis of the suitability of individual IPSAS standards. Retrieved from http://www.pwc.be/en/publications/2014/epsas_oct_2014.pdf

Reischmann, M. (2016). Creative accounting and electoral motives: Evidence from OECD countries. Journal of Comparative Economics, 44(2), 243-257. https://doi.org/10.1016/j.jce.2015.07.001

Robinson, M. (1998). Accrual accounting and the efficiency of the core public sector. Financial Accountability and Management, 14(1), 21-37. https://doi.org/10.1111/1468-0408.00048

Seifert, J., Carlitz, R., \& Mondo, E. (2013). The open budget index (OBI) as a comparative statistical tool. Journal of Comparative Policy Analysis: Research and Practice, 15(1), 87-101. https://doi.org/10.1080/13876988.2012.748586

Sellami, Y. M., \& Gafsi, Y. (2017). Institutional and economic factors affecting the adoption of international public sector accounting standards. International Journal of Public Administration, 1(13), 190-692. https://doi.org/10.1080/01900692.2017.1405444

The Economist Group. (n.d.). Democracy index 2017. Retrieved from http://www.eiu.com/topic/democracy-index

Wang, R. F., Irwin, T. C., \& Murara, L. K. (2015). Trends in fiscal transparency: Evidence from a new database of the coverage of fiscal reporting [IMF Working Papers, WP/15/188]. International Monetary Fund. https://doi.org/10.5089/9781513523965.001

Weber, A. (2012). Stock-flow adjustments and fiscal transparency: A cross-country comparison [IMF Working Papers, WP/12/39]. International Monetary Fund. https://doi.org/10.5089/9781463933821.001 
Wehner, J., \& Renzio, P. de. (2013). Citizens, legislators, and executive disclosure: The political determinants of fiscal transparency. World Development, 41(January), 96-108. https://doi.org/10.1016/j.worlddev.2012.06.005

World Bank. (n.d.b). Central government debt, total (\% of GDP) [Database]. Retrieved from https://data.worldbank.org/indicator/GC.DOD.TOTL.GD.ZS

World Bank. (n.d.c). GDP per capita, PPP (current international \$) [Database]. Retrieved from https://data.worldbank.org/indicator/NY.GDP.PCAP.PP.CD

World Bank. (n.d.d). Population, total [Database]. Retrieved from https://data.worldbank.org/indicator/SP.POP.TOTL

World Bank. (n.d.a). Rule of law [Data file]. Retrieved from http://info.worldbank.org/governance/wgi/pdf/rl.pdf

Zimmerman, J. L. (1977). The municipal accounting maze: An analysis of political incentives. Journal of Accounting Research, 15(Supplement), 107-144. https://doi.org/10.2307/2490636

\section{Authors}

Sigit Wahyu Kartiko

Directorate General of Fiscal Balance, Ministry of Finance, Dr. Wahidin Raya Street No. 1, Radius Prawiro Building, 9th Floor, Central Jakarta, DKI Jakarta, 10710, Indonesia. E-mail address: gsigit@ gmail.com. http://orcid.org/0000-0002-6581-8706

Hilda Rossieta

University of Indonesia, Faculty of Economics and Business, Prof. Dr. Sumitro Djojohadikusumo Street, Dekanat Building of FEB UI, Depok, West Java, 16424, Indonesia. E-mail address: enjum9@ gmail.com. http://orcid.org/0000-0002-7898-2433

Dwi Martani

University of Indonesia, Faculty of Economics and Business, Prof. Dr. Sumitro Djojohadikusumo Street, Dekanat Building of FEB UI, Depok, West Java, 16424, Indonesia. E-mail address: dwimartani@ yahoo.com. http://orcid.org/0000-0001-9977-2147

Trisacti Wahyuni

University of Indonesia, Faculty of Economics and Business, Prof. Dr. Sumitro Djojohadikusumo Street, Dekanat Building of FEB UI, Depok, West Java, 16424, Indonesia. E-mail address: trisacti_wahyuni@yahoo.com. http://orcid.org/0000-00027879-2074 


\section{APPENDIX A}

\section{Prior Sudies of Accrual-based IPSAS Measurements}

\begin{tabular}{|c|c|c|c|c|c|c|}
\hline & $\begin{array}{l}\text { Sellami and Gafsi } \\
\text { (2017) }\end{array}$ & $\mathrm{PwC}(2013)$ & $\begin{array}{l}\text { Christiaens et al. } \\
\text { (2014) }\end{array}$ & Pina and Torres (2003) & Benito et al. (2007) & PwC (2014) \\
\hline Purpose of Study & $\begin{array}{l}\text { determinants of } \\
\text { IPSAS adoptions }\end{array}$ & $\begin{array}{l}\text { mapping of accounting } \\
\text { basis }\end{array}$ & $\begin{array}{l}\text { mapping of IPSAS(- } \\
\text { like) accrual adopters }\end{array}$ & Mapping of IPSAS adopters & $\begin{array}{l}\text { analyzed IPSAS } \\
\text { convergence across } \\
\text { countries }\end{array}$ & $\begin{array}{l}\text { analyzed accounting maturity } \\
\text { level for EPSAS initiative }\end{array}$ \\
\hline \multicolumn{7}{|l|}{ Highlighting: } \\
\hline Main Presentations & no & no & no & yes & yes & yes \\
\hline \multicolumn{7}{|l|}{ Accounting Policies: } \\
\hline $\begin{array}{l}\text { Revenues; Expense; } \\
\text { Inventories; Investment; } \\
\text { PPE; Employee Benefits; } \\
\text { Financial Liab; Provision \& } \\
\text { Cont. Liab.; }\end{array}$ & no & no & no & no & $\begin{array}{l}\text { partially; yes; yes; yes; } \\
\text { yes; no; yes; yes; }\end{array}$ & $\begin{array}{c}\text { yes; yes; yes; yes; yes; yes; } \\
\text { yes; yes; }\end{array}$ \\
\hline \multicolumn{7}{|l|}{ Measure: } \\
\hline Types & Binary & Categorical & Categorical & Continues (in \%) & Continues (in \%) & Continues (in \%) \\
\hline Measurement & $\begin{array}{l}\text { IPSAS vs. non IPSAS } \\
\text { adopter }\end{array}$ & $\begin{array}{l}\text { four categories: cash, } \\
\text { modified cash, modified } \\
\text { accrual, and full accrual }\end{array}$ & $\begin{array}{l}\text { three categories: } \\
\text { IPSAS accrual, IPSAS } \\
\text { (-like) accrual, cash }\end{array}$ & $\begin{array}{l}\text { Completeness of main } \\
\text { presentation accounts (i.e., } \\
\text { balance sheet: account } \\
\text { receivable, account payables, } \\
\text { etc.) }\end{array}$ & $\begin{array}{l}\text { Recognition and } \\
\text { measurement conformity } \\
\text { level }\end{array}$ & $\begin{array}{l}\text { Recognition, measurement, } \\
\text { and presentation maturity } \\
\text { level }\end{array}$ \\
\hline Is accrual-based IPSAS? & $\begin{array}{l}\text { not necessarily, cash- } \\
\text { based IPSAS is } \\
\text { included }\end{array}$ & not necessarily & yes & yes & yes & $\begin{array}{c}\text { yes but not necessarily } \\
\text { conformed to IPSASs and } \\
\text { ESAs }\end{array}$ \\
\hline Sample of countries & $\begin{array}{l}110 \text { OECD and non- } \\
\text { OECD }\end{array}$ & $\begin{array}{l}100 \text { OECD and non- } \\
\text { OECD }\end{array}$ & $\begin{array}{l}59 \text { of OECD and non- } \\
\text { OECD }\end{array}$ & 17 Europeans & 15 OECD & 9 Europeans \\
\hline Periode & 2014 & 2012 & 2012 & 2002 & 2003 & 2013 \\
\hline
\end{tabular}




\section{APPENDIX B}

\section{Predicted CFA Estimation of Central Governments Accrual Policy Levels}

\begin{tabular}{|c|c|c|c|c|c|c|c|c|c|c|c|c|c|c|c|c|c|}
\hline \multirow{2}{*}{$\begin{array}{c}\text { Central } \\
\text { Governments }\end{array}$} & \multirow{2}{*}{ IPSAS } & \multicolumn{2}{|c|}{ Accrual policy } & \multicolumn{2}{|c|}{$\begin{array}{c}\text { Fiscal } \\
\text { transparency }\end{array}$} & \multirow{2}{*}{$\begin{array}{c}\text { Central } \\
\text { Governments }\end{array}$} & \multirow{2}{*}{ IPSAS } & \multicolumn{2}{|c|}{ Accrual policy } & \multicolumn{2}{|c|}{$\begin{array}{c}\text { Fiscal } \\
\text { transparency }\end{array}$} & \multirow{2}{*}{$\begin{array}{c}\text { Central } \\
\text { Governments }\end{array}$} & \multirow{2}{*}{ IPSAS } & \multicolumn{4}{|c|}{$\begin{array}{c}\text { Fiscal } \\
\text { Accrual policy transparency }\end{array}$} \\
\hline & & ‘08-15 & Rank & $\begin{array}{l}‘ 08- \\
15\end{array}$ & Rank & & & ‘08-15 & Rank & ‘08-15 & Rank & & & ‘08-15 & Rank & ‘08-15 & Rank \\
\hline New Zealand* & A & 74.89 & 1 & 89.7 & 1 & Indonesia & & 22.26 & 26 & 56.91 & 27 & Liberia & & 5.86 & 52 & 35.05 & 59 \\
\hline United Kingdom* & & 72.86 & 2 & 83.23 & 4 & Bulgaria & A & 21.16 & 27 & 61.91 & 19 & Uganda & & 5.76 & 53 & 59.9 & 22 \\
\hline United States* & & 60.86 & 3 & 80.82 & 7 & Brazil & & 20.96 & 28 & 74.28 & 8 & Namibia & & 5.66 & 54 & 49.92 & 39 \\
\hline Peru & A & 55.46 & 4 & 66.87 & 14 & Romania & & 19.96 & 29 & 62.33 & 18 & Algeria & & 5.56 & 55 & 10.85 & 77 \\
\hline Costa Rica & A & 50.26 & 5 & 50.03 & 38 & Honduras & A & 17.16 & 30 & 33.54 & 62 & China & & 5.56 & 55 & 12.86 & 75 \\
\hline Chile* & A & 48.36 & 6 & 64.43 & 16 & Philippines & A & 16.76 & 31 & 55.9 & 29 & Zambia & & 5.46 & 57 & 30.49 & 64 \\
\hline Sweden* & A & 47.76 & 7 & 84.24 & 3 & Hungary* & & 15.16 & 32 & 48.9 & 41 & Bangladesh & & 5.06 & 58 & 52.75 & 32 \\
\hline Spain* & & 46.16 & 8 & 61.02 & 21 & El Salvador & & 14.36 & 33 & 44.62 & 50 & Nepal & & 4.96 & 59 & 36.85 & 58 \\
\hline Slovak Republic* & & 44.96 & 9 & 59.72 & 23 & Italy* & & 13.16 & 34 & 64.85 & 15 & Kenya & & 4.76 & 60 & 49.81 & 40 \\
\hline Thailand & A & 42.76 & 10 & 40.5 & 55 & Bosnia Herzegovina & A & 13.06 & 35 & 45.28 & 46 & Kazakhstan & & 4.66 & 61 & 45.03 & 48 \\
\hline France* & & 42.46 & 11 & 81.71 & 6 & Ukraine & A & 12.86 & 36 & 52.97 & 31 & Lebanon & & 4.66 & 61 & 21.07 & 69 \\
\hline Colombia & A & 41.76 & 12 & 58.6 & 25 & Sri Lanka & & 10.86 & 37 & 50.72 & 36 & Mozambique & & 4.66 & 61 & 37.83 & 57 \\
\hline Norway* & $\mathrm{A}$ & 38.36 & 13 & 83.05 & 5 & Croatia & & 10.46 & 38 & 56.8 & 28 & Senegal & & 4.66 & 61 & 19.69 & 71 \\
\hline Argentina & A & 37.36 & 14 & 55.82 & 30 & Sierra Leone & & 10.16 & 39 & 46.98 & 44 & Mali & & 4.36 & 65 & 42.2 & 52 \\
\hline Bolivia & A & 36.86 & 15 & 13.47 & 74 & Serbia & & 10.06 & 40 & 46.51 & 45 & Georgia & & 4.26 & 66 & 59 & 24 \\
\hline Germany* & & 35.66 & 16 & 69.41 & 10 & Ghana & & 9.46 & 41 & 51.51 & 34 & Nigeria & & 4.26 & 66 & 19.72 & 70 \\
\hline Slovenia* & & 33.86 & 17 & 70.45 & 9 & Albania & & 9.26 & 42 & 38.91 & 56 & Angola & & 3.86 & 68 & 23.53 & 68 \\
\hline Korea, Rep.* & & 32.46 & 18 & 69.38 & 11 & Malaysia & & 9.26 & 42 & 40.79 & 54 & Egypt & & 3.86 & 68 & 26.99 & 66 \\
\hline
\end{tabular}




\begin{tabular}{|c|c|c|c|c|c|c|c|c|c|c|c|c|c|c|c|c|c|}
\hline \multirow{2}{*}{$\begin{array}{c}\text { Central } \\
\text { Governments }\end{array}$} & \multirow{2}{*}{ IPSAS } & \multicolumn{2}{|c|}{ Accrual policy } & \multicolumn{2}{|c|}{$\begin{array}{c}\text { Fiscal } \\
\text { transparency }\end{array}$} & \multirow{2}{*}{$\begin{array}{c}\text { Central } \\
\text { Governments }\end{array}$} & \multirow{2}{*}{ IPSAS } & \multicolumn{2}{|c|}{ Accrual policy } & \multicolumn{2}{|c|}{$\begin{array}{c}\text { Fiscal } \\
\text { transparency }\end{array}$} & \multirow{2}{*}{$\begin{array}{c}\text { Central } \\
\text { Governments }\end{array}$} & \multirow{2}{*}{ IPSAS } & \multicolumn{4}{|c|}{$\begin{array}{c}\text { Fiscal } \\
\text { Accrual policy } \text { transparency }\end{array}$} \\
\hline & & ‘08-15 & Rank & $\begin{array}{l}‘ 08- \\
15\end{array}$ & Rank & & & ‘08-15 & Rank & ‘08-15 & Rank & & & ‘08-15 & Rank & ‘08-15 & Rank \\
\hline Turkey* & A & 30.66 & 19 & 48.64 & 42 & Czech Republic** & & 8.76 & 44 & 67.85 & 13 & Burkina Faso & & 3.66 & 70 & 24.92 & 67 \\
\hline Dominican Rep. & A & 29.86 & 20 & 31.35 & 63 & Guatemala & & 8.56 & 45 & 48.19 & 43 & Botswana & & 3.56 & 71 & 50.47 & 37 \\
\hline Russian Federation & & 28.16 & 21 & 68.67 & 12 & Trinidad Tobago & & 8.56 & 45 & 34.49 & 60 & Cambodia & & 3.06 & 72 & 11.55 & 76 \\
\hline Mongolia & $\mathrm{A}$ & 27.36 & 22 & 51.33 & 35 & Pakistan & & 7.96 & 47 & 44.88 & 49 & Vietnam & & 2.66 & 73 & 16.06 & 73 \\
\hline Portugal* & & 26.46 & 23 & 61.66 & 20 & India & & 7.36 & 48 & 58.37 & 26 & Malawi & & 2.56 & 74 & 52.61 & 33 \\
\hline Poland* & & 23.96 & 24 & 63.26 & 17 & FYR Macedonia & & 7.26 & 49 & 41.09 & 53 & Rwanda & & 2.46 & 75 & 18.24 & 72 \\
\hline \multirow[t]{2}{*}{ South Africa } & & 23.46 & 25 & 88.96 & 2 & Tanzania & A & 7.16 & 50 & 44.36 & 51 & Azerbaijan & & 1.26 & 76 & 45.1 & 47 \\
\hline & & & & & & Morocco & & 6.16 & 51 & 34.2 & 61 & Benin & & 0.36 & 77 & 27.72 & 65 \\
\hline
\end{tabular}

Note. Source: authors' calculation.

Average accrual policy level and fiscal transparency from 2008 to 2015. A = adopter, country that explicitly refers to accrual-based IPSAS until 2015. Accrual policy level latent variable is predicted from first order CFA estimation and rescaled to scores from 0-100. Fiscal transparency is based-on Open Budget Index (OBI) survey.

* OECD countries. 